\title{
POŽÁRNÍ ODOLNOST ZELENÝCH PLOCHÝCH STŘECH
}

\author{
FIRE RESISTANCE TESTING OF GREEN FLAT ROOFS
}

\author{
Klára Hobzová ${ }^{*}, 1$, Martin Pilinszki ${ }^{1}$, Petr Beneš ${ }^{1}$
}

"hobzova.k@vutbr.cz

${ }^{1}$ Vysoké učení technické v Brně, Fakulta stavební, Veveří 331/95, 60200 Brno

\begin{abstract}
Abstrakt
Požadavky na plášt' střechy s vegetačním souvrstvím, z pohledu požární bezpečnosti, nejsou v dnešní době v České republice přímo definovány. Pro klasifikaci střech / stř̌ešních krytin vystavené působení vnějšího požáru se dle ČSN P CEN/TS 1187:2012 používají čtyři zkušební metody. Podkladem pro určení požární odolnosti zelené střechy jsou protokoly o klasifikaci zpracované dle dané normy (střešní pláště zařazené do třídy Broof (t3) nešíří požár a brání vznícení hořlavých částí konstrukce).

Článek se zabývá zkoušením požární odolnosti zelené intenzivní střechy dle vlastní metodiky, která vychází ze zkoušky Broof (t3). Byl sledován průběh teplot v jednotlivých vrstvách stř̌šního pláště. Z teplotních čidel se určila maximální teplota pod travním kobercem, dále pak maximální nárůst teploty $150 \mathrm{~mm}$ a $300 \mathrm{~mm}$ pod povrchem. Nakonec se změřil rozsah šíření plamene po povrchu.

Cílem bylo určit vliv vnějšího požáru na nosnou konstrukci střešního pláště, dále pak zatřídit konstrukci do př́slušné klasifikace dle ČSN EN 13501-5:2017.
\end{abstract}

\section{Klíčová slova}

Požární odolnost, požární zkouška, zelená intenzivní střecha, průběh teplot

\begin{abstract}
The requirements for the roof covering with a vegetation layer, from the point of view of fire safety, are not currently directly defined in the Czech Republic. According to ČSN P CEN / TS 1187: 2012, four test methods are used for the classification of roofs / roof coverings exposed to external fire. The basis for determining the fire resistance of a green roof are classification protocols prepared according to the standard (roof coverings classified in the Broof (t3) class do not spread fire and prevent ignition of flammable parts of the structure).

The article deals with testing the fire resistance of a green intensive roof according to our own methodology, which is based on the Broof ( $\mathrm{t} 3$ ) test. The course of temperatures in individual layers of the roof cladding was monitored. The maximum temperature under the grass was determined from the temperature sensors, followed by the maximum temperature rise of $150 \mathrm{~mm}$ and $300 \mathrm{~mm}$ below the surface. Finally, the extent of flame spread across the surface was measured.

The aim was to determine the effect of external fire on the supporting structure of the roof cladding, then to classify the structure into the appropriate classification according to ČSN EN 13501-5: 2017.
\end{abstract}

\section{Key words}

Fire resistance, fire test, green intensive roof, temperature course

\section{1 ÚVOD}

Článek se zabývá posouzením požární odolnosti střešního souvrství intenzivní zelené ploché střechy za účelem hodnocení odolnosti při působení vnějšího požáru. Pro účely klasifikace střech / střešních krytin se používají čtyři zkušební metody uvedené v ČSN P CEN/TS 1187:2012 - Zkušební metody pro střechy vystavené působení vnějšího požáru [1]. Uvažuje-li se pouze klasifikace Broof (t3), Croof (t3) nebo Droof (t3), uskuteční se pouze zkouška $3 \mathrm{~s}$ hořícími hraničkami, větrem a přídavným sálavým teplem. Tato zkouška byla provedena dle vlastní metodiky. Zkouška probíhala za skutečných podmínek ve venkovním prostředí. Zkoušelo se na vzorku ve sklonu $5^{\circ}$ o velikosti $2 \times 1 \mathrm{~m} \mathrm{~s}$ mocností substrátu $300 \mathrm{~mm}$. Byla měřena teplota venkovního vzduchu a rychlost větru. Na povrch vzorku byly položeny hraničky, které svou přípravou i rozměry odpovídaly výše zmíněné normové 
zkušební metodě. Zkouška probíhala po dobu 33 minut, kde byly zaznamenávány probíhající teploty ve třech výškových úrovních střešního pláště.

Cílem zkoušky bylo ověřit teplotu na nosné konstrukci střechy, zda působení vnějšího požáru může tuto konstrukci narušit. Dále bylo cílem zatřídit danou konstrukci dle klasifikačních parametrů z ČSN EN 135015:2017 - Klasifikace podle výsledků zkoušek střech vystavených vnějšímu požáru [2] do klasifikace Broof (t3).

\section{POPIS SOUČASNÉHO STAVU}

V současnosti nejsou v České republice specifikovány požadavky z hlediska požární bezpečnosti zelených střech. Návrh zelených střech a požadovaných odstupových vzdáleností je uvažován za dodržení předpokladů realizace:

- výšky minerálního substrátu $>30 \mathrm{~mm}$,

- nízké vegetace, která je málo náchylná $\mathrm{k}$ hoření,

- S štěrkového pásu nebo dlažby šířky 500 mm kolem prostupů, světlíků, střrešních oken, atik, vyčnívajících konstrukcí apod. [3].

Z hlediska šíření požáru po povrchu střechy se rozlišuje, zda je střecha nebo její část v požárně nebezpečném prostoru (PNP) nebo mimo něj. Pokud je střecha v požárně nebezpečném prostoru, to znamená zjednodušeně, že na ni mohou padat hořící části, př́ípadně se na ní může šířit oheň z jiné části stavby, je třeba, aby splňovala klasifikaci Broof (t3), čili aby byla odzkoušena v požární zkušebně na tuto klasifikaci. Zkušební vzorek skladby střechy je vystaven působení ohně, větru a sálavého tepla a musí vyhovět několika daným kritériím.

Pokud je střecha mimo PNP a její plocha je do $1500 \mathrm{~m}^{2}$, nemusí mít žádnou klasifikaci. Pokud její plocha přesahuje $1500 \mathrm{~m}^{2}$, musí mít klasifikaci Broof (t1), která se prokazuje rovněž zkouškou, vzorek je zde ale vystaven pouze ohni, nikoliv sálavému teplu a větru. Druhou možností, kterou uvádí norma, je rozdělení střechy na části s plochou menší než $1500 \mathrm{~m}^{2}$ pruhy šířky $2 \mathrm{~m}$ s klasifikací Broof (t3). Uvedené požadavky se z důvodu velikosti plochy netýká rodinných domů a obvykle ani bytových domů. Řešit je to však nutné např. u střech velkých hal.

Z hlediska požární odolnosti musí střechy splňovat požadavky R, RE nebo REI. Požární odolnost je stanovena v minutách dle stupně požární bezpečnosti, který závisí na druhu konstrukčního systému, výpočtovém požárním zatížení a požární výšce. Každopádně např. u nejvyšších stupňů požární bezpečnosti (VI a VII) je kromě času v minutách předepsána konstrukce typu DP1. To jsou konstrukce, které nezvyšují v požadované době intenzitu požáru a sestávají se především z nehořlavých materiálů a výrobků (trrída reakce na oheň A1 nebo A2).

Pro hodnocení odolnosti konstrukcí vưči účinkům požáru jsou konstrukce klasifikovány na základě, již výše zmíněných, mezních stavů s požární odolností v minutách. Hodnoty jednotlivých kritérií jsou získány z výsledků požárních zkoušek [4]. Pro průběh zkoušky zelených plochých střech je důležité dodržení předem stanovených postupů, jejichž hlavními parametry jsou sklon střešní konstrukce, rychlost větru, laboratorní teplota, rozměry zkušebních vzorků a hořící hraničky, kterým je konstrukce vystavena.

\section{METODIKA}

Zkoušený vzorek:

- travní koberec,

- $\quad$ substrát tl. $300 \mathrm{~mm}$.

\section{Postup řešení dle vlastní metodiky}

V průběhu zkoušky se měřil tlak vzduchu, rychlost větru, teplota okolního vzduchu a průběhy teplot v konstrukci.

Tlak vzduchu: $1020 \mathrm{hPa}$

Rychlost větru: $\quad 0-0,35 \mathrm{~m} / \mathrm{s}$

Exteriérová teplota: $\quad 7,3-8,2{ }^{\circ} \mathrm{C}$

Vzorek pro experimentální zkoušku byl o rozměru 1000 x $2000 \mathrm{~mm}$, uložen ve sklonu $5^{\circ}$. Zkouška proběhla ve venkovním prostředí tak, aby co nejvíce odpovídala reálném průběhu požáru na povrchu zelené střechy.

Hraničky byly vyrobeny celkem ze čtyř kusů dřevovláknité desky o hustotě $230 \mathrm{~kg} / \mathrm{m}^{3}$, každý o rozměru 55 x 16 × $25 \mathrm{~mm}$, které byly spojeny do mřížky o podstavě 55 x $55 \mathrm{~mm}$ a výšce $32 \mathrm{~mm}$. Před započetím zkoušky byly hraničky 5 min dopředu namočeny do n-heptanového roztoku, poté se usadili na vzorek ve vzdálenosti $500 \mathrm{~mm}$ od spodní hrany a $500 \mathrm{~mm}$ od boční hrany (orientace je v podélném směru vzorku). 


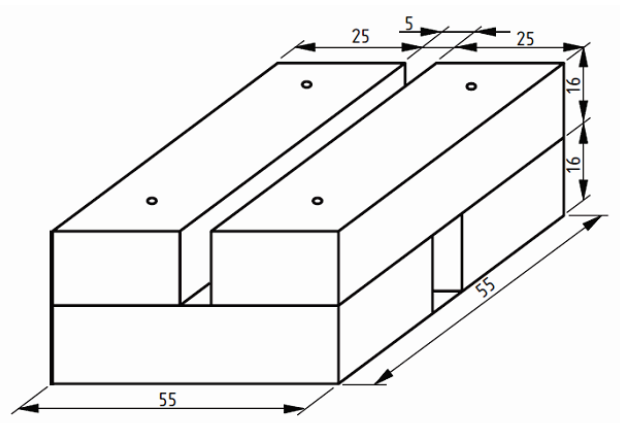

Obr. 1 Hraničky [1].

V časovém intervalu po 1 sekundě se zaznamenávala teplota na jednotlivých čidlech. Čidlo 1 je umístěno pod travním kobercem, čidlo 2 je umístěno $150 \mathrm{~mm}$ pod čidlem 1, čidlo 3 je umístěno $300 \mathrm{~mm}$ pod čidlem 1 .

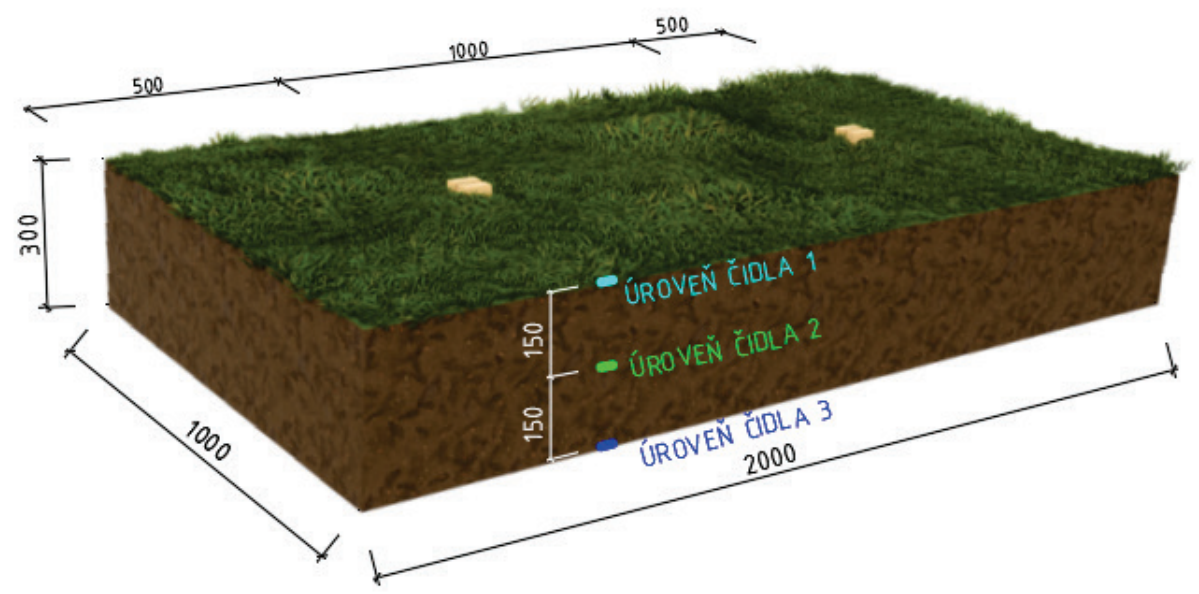

Obr. 2 Umístění hraniček a čidel.

Během zkoušky se dále sledoval čas vzplanutí, stékající a odkapávající hořící částice. Po skončení zkoušky se změřil rozsah šíření plamene po povrchu.

Zkouška probíhala po dobu $33 \mathrm{~min}$.

\section{VÝSLEDKY}

Zkouška byla provedena v celkové délce 33 minut. Během této doby byly z jednotlivých čidel zaznamenávány naměřené teploty.

V čase 40 sekund byly hraničky zapáleny, a tak došlo ke zvyšování teplot na prvním čidle. Nejvyšší teploty $\left(90,6^{\circ} \mathrm{C}\right)$ bylo dosaženo v čase 13 minut a 8 sekund od začátku zkoušky. konstantní.

$\mathrm{Na}$ druhém čidle byla během zkoušky maximální změna teploty $0,2^{\circ} \mathrm{C}$. Na třetím čidle zůstala teplota

Dle doby vnějšího šíření požáru $\mathrm{T}_{\mathrm{E}}$ a doby prohoření $\mathrm{T}_{\mathrm{p}}$ bylo určeno zatřídění do skupiny Broof (t3) dle normy ČSN EN 13501-5:2017 [2]. Konstrukce střešní krytiny (trávníkový koberec) př́i vnějším působení požáru splňuje požadavky $\mathrm{T}_{\mathrm{E}}$ a $\mathrm{T}_{\mathrm{p}} \geq 30$ minut. 


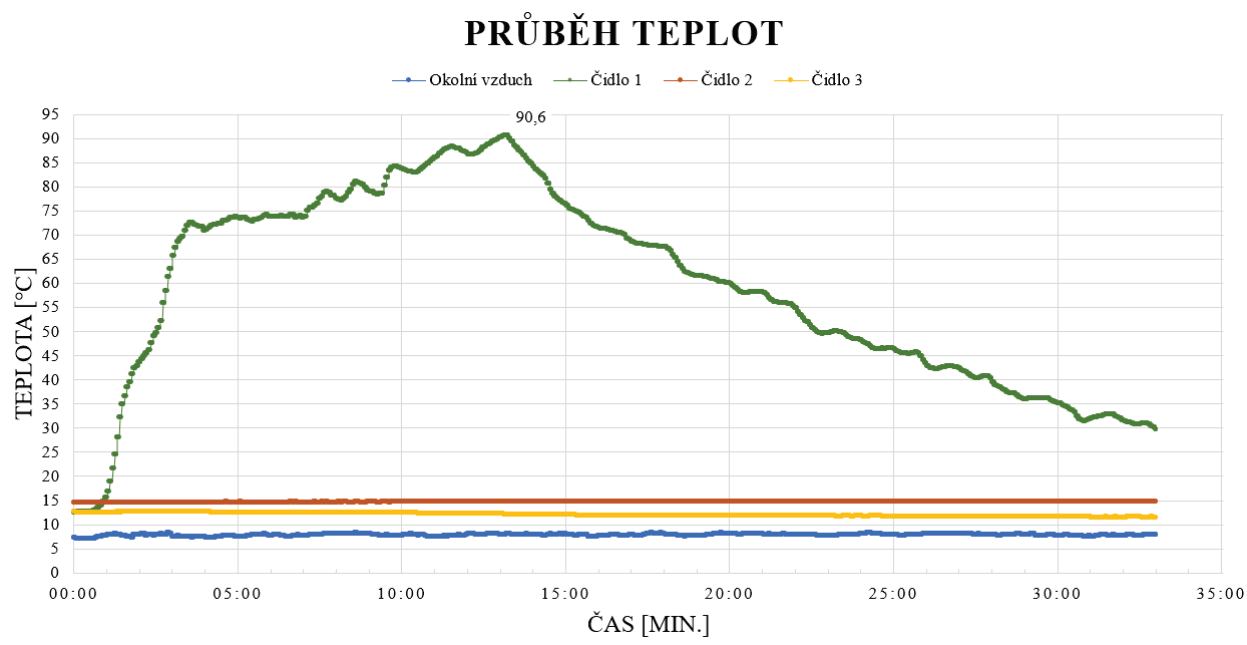

Obr. 3 Naměřené průběhy teplot.

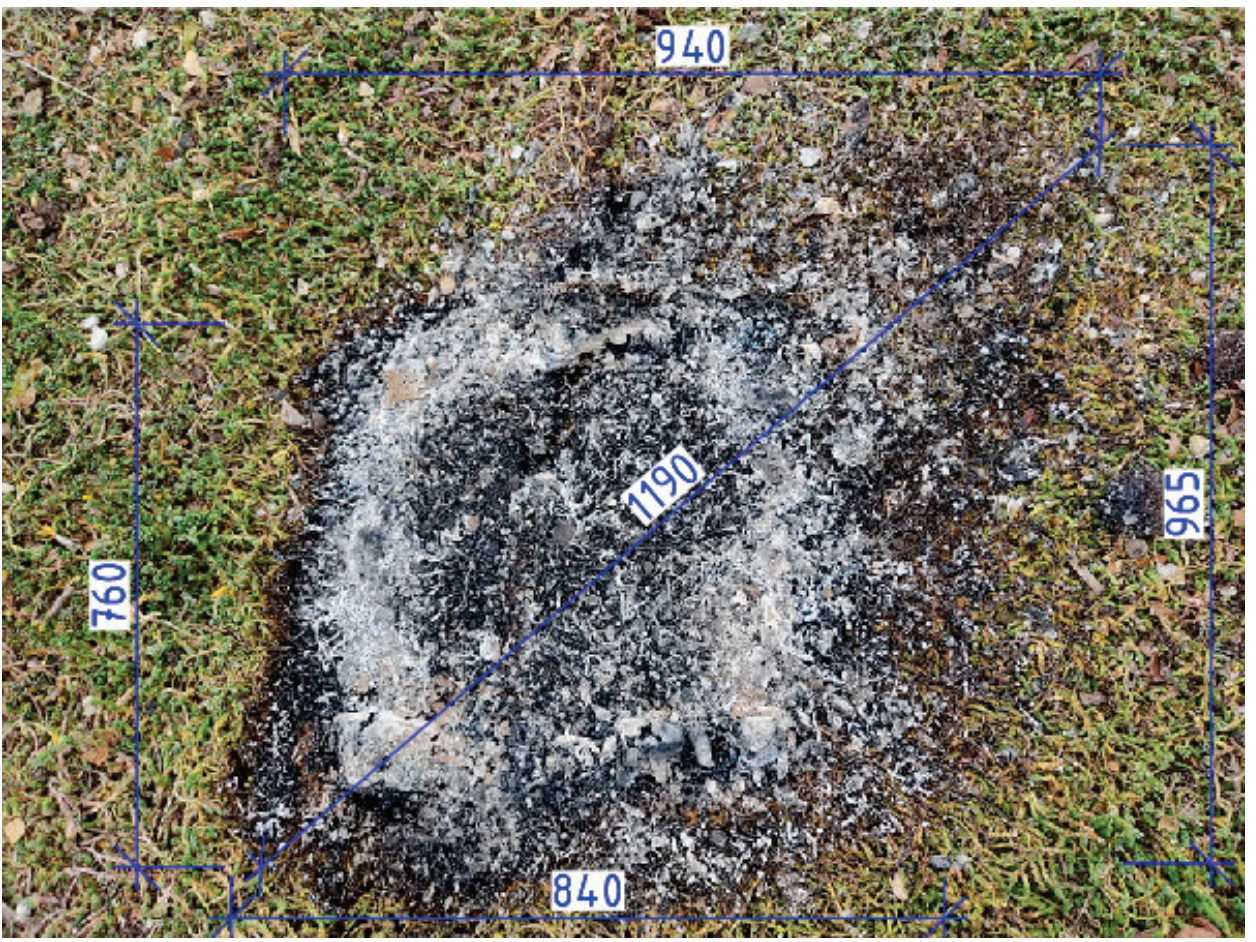

Obr.4 Rozsah šíření plamene po povrchu. 


\section{DISKUZE}

Dle naměřených výsledků byla maximální dosažená teplota při působení vnějšího požáru na zelenou střechu $90,6^{\circ} \mathrm{C}$, kdy tato teplota byla naměřena pod trávníkovým kobercem. Při mocnosti substrátu $150 \mathrm{~mm}$ se teplota změní o $0,2^{\circ} \mathrm{C}$ a při mocnosti $300 \mathrm{~mm}$ již zůstává konstantní. Z těchto výsledků vyplývá, že při působení vnějšího požáru na zelenou střechu, již při mocnosti substrátu $150 \mathrm{~mm}$, nemá vnější požár vliv na nosnou konstrukci střešního pláště.

Při této zkoušce budou ovšem důležité podmínky měření. Nejedná se jen o teplotu vzduchu, ale také o vlhkost použitého substrátu a stavu zeleně na povrchu pláště.

Studie o tepelném obsahu vegetace ukázaly, že do značné míry závisí na rostlinných druzích. Bylo pozorováno, že rostoucí médium ve vlhkém stavu nepředstavuje riziko požáru, u suchých podkladů byla v první minutě zaznamenána maximální rychlost uvolňování tepla až $3 x$ větší než u médií ve vlhkém stavu, v druhé minutě se pak rychle snížila na stejnou jak u médií ve vlhkém stavu. [5]

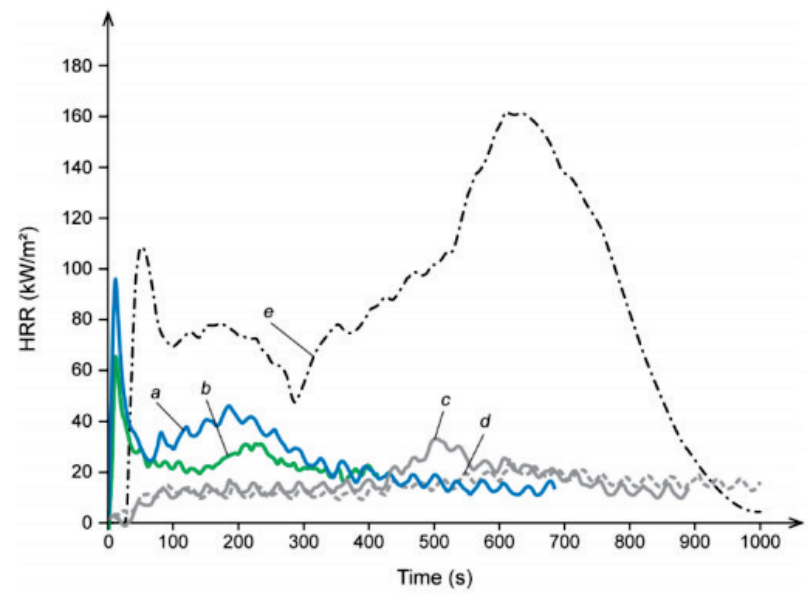

Obr.5: Porovnání rychlosti uvolňování tepla (HRR) zelených střech v suchém a vlhkém stavu s typická střešní krytinou: (a) substrát 1 (obsah vlhkosti 0\%); (b) substrát 2 (0\%); (c) Substrát 1 (30\%); (d) substrát $2(30 \%)$; e) polymerem modifikovaná bitumenová membrána s požárními pásy [5]

Tato zkouška byla přínosná pro získání základního přehledu průběhu teplot v konstrukci při působení vnějšího požáru a šíření plamene po povrchu zelených střech. Nicméně, pro získání adekvátních výsledků by bylo nutné provést měření na více druzích zeleně ve vlhkém i suchém stavu.

\section{ZÁVĚR}

Z provedeného měření vyplývá, že při působení vnějšího požáru na zelenou střechu, již při mocnosti substrátu $150 \mathrm{~mm}$, nemá vnější požár vliv na nosnou konstrukci střešního pláště. Tento závěr ovšem nelze brát obecně na všechny typy zelených střech. Je nutné se dále zabývat jednotlivými vlivy, které mohou intenzitu požáru ovlivnit. Z publikace výše uvedené: Flammability Characteristics of Green Roofs [5] vyplývají souvislosti mezi vlhkostí substrátu a rychlostí uvolňování tepla, které by bylo potřeba dále podrobně rozpracovat s ohledem na zelenou vrstvu střechy.

\section{Poděkování}

Tento př́spěvek byl financován v rámci projektu č. FAST-J-21-7428 "Požární odolnost intenzivní zelené ploché střechy ". 


\section{Použité zdroje}

[1] ČSN P CEN/TS 1187:2012 - Zkušební metody pro střechy vystavené působení vnějšího požáru. 2012.

[2] ČSN EN 13501-5:2017 - Požární klasifikace stavebních výrobků a konstrukcí staveb - Č́st 5: klasifikace podle výsledků zkoušek střech vystavených vnějšímu požáru. 2017

[3] [online]. Copyright Cx [cit. 07.11.2021]. Dostupné z: http://www.otevrenazahrada.cz/OZ/files/e6/e664e296-a5f4-4c69-930c-978627e269d2.pdf

[4] Ploché střechy a jejich požární bezpečnost. Jaké požadavky musí konstrukce splňovat? - ESTAV.cz. ESTAV.cz - Architektura. Stavba. Bydlení. [online]. Copyright C Copyright [cit. 07.11.2021]. Dostupné z: https://www.estav.cz/cz/6668.ploche-strechy-z-hlediska-pozarni-ochrany-jakepozadavky-musi-konstrukce-splnovat

[5] GERZHOVA, Nataliia, Pierre BLANCHET, Christian DAGENAIS, Sylvain MÉNARD a Jean CÔTÉ. Flammability Characteristics of Green Roofs. 2020, 13

[6] GERZHOVA, Nataliia, Pierre BLANCHET, Christian DAGENAIS, Jean CÔTÉ a Sylvain MÉNARD, Heat Transfer Behavior of Green Roof Systems under Fire Condition: A Numerical Study, 2019

[7] GERZHOVA, Nataliia, Pierre BLANCHET, Christian DAGENAIS a Sylvain MÉNARD, A Conceptual Framework for Modelling the Termal Conductivity of Dry Green Roof Substrates, 2019 